\title{
The Landscape of Diabetic Kidney Disease in the United States
}

\author{
O. Kenrik Duru ${ }^{1} \cdot$ Tim Middleton $^{2} \cdot$ Mona K. Tewari $^{2} \cdot$ Keith Norris $^{1}$
}

Published online: 19 February 2018

(C) The Author(s) 2018. This article is an open access publication

\begin{abstract}
Purpose of Review The purposes of this review are to identify population characteristics of important risk factors for the development and progression of diabetic kidney disease (DKD) in the United States and to discuss barriers and opportunities to improve awareness, management, and outcomes in patients with DKD.

Recent Findings The major risk factors for the development and progression of DKD include hyperglycemia, hypertension, and albuminuria. DKD disproportionately affects minorities and individuals with low educational and socioeconomic status. Barriers to effective management of DKD include the following: (a) limited patient and healthcare provider awareness of DKD, (b) lack of timely referrals of patients to a nephrologist, (c) low patient healthcare literacy, and (d) insufficient access to healthcare and health insurance.

Summary Increased patient and physician awareness of DKD has been shown to enhance patient outcomes. Multifactorial and multidisciplinary interventions targeting multiple risk factors and patient/physician education may provide better outcomes in patients with DKD.
\end{abstract}

Keywords Albuminuria $\cdot$ Diabetes $\cdot$ Diabetic kidney disease $\cdot$ Chronic kidney disease

\section{Introduction}

Diabetes mellitus is the major cause of chronic kidney disease (CKD) and end-stage renal/kidney disease (ESRD/ESKD) in the United States [1•] and globally [2]. In 2012, the estimated prevalence of diabetes (both diagnosed and undiagnosed) in the United States was 9\% to 14\% [3, 4]. Diabetes disproportionately affects non-Hispanic blacks (22\%) and Hispanics

This article is part of the Topical Collection on Microvascular Complications-Nephropathy

Electronic supplementary material The online version of this article (https://doi.org/10.1007/s11892-018-0980-x) contains supplementary material, which is available to authorized users.

O. Kenrik Duru

Kduru@mednet.ucla.edu

1 Department of Medicine, Division of General Internal Medicine/ Health Services Research, David Geffen School of Medicine at the University of California, Los Angeles, 10940 Wilshire Blvd, Suite 700, Los Angeles, CA 90024, USA

2 AbbVie, North Chicago, IL, USA
(23\%) and those with the lowest levels of education (19\%) and income (18\%) [4]. Type 2 diabetes mellitus (T2DM) accounts for $90 \%$ to $95 \%$ of all cases of diagnosed diabetes [3].

Approximately $25 \%$ of individuals with diabetes have diabetic kidney disease (DKD) [5•], which refers to CKD presumed to be caused by diabetes [6]. DKD is commonly diagnosed by reduced estimated glomerular filtration rate (eGFR $<60 \mathrm{~mL} / \mathrm{min} / 1.73 \mathrm{~m}^{2}$ ) and/or increased urinary albumin excretion ( $>30 \mathrm{mg} / \mathrm{g}$ creatinine), a marker of kidney damage, that persist $\geq 3$ months in the presence of longstanding diabetes and exclusion of other causes of CKD [7,8]. In the United States, the prevalence of DKD will likely increase owing to a projected 54\% increase in the prevalence of diabetes by 2030 [9].

Based on data from the United States Renal Data System (USRDS), the overall prevalence of CKD (stages 1-5) in the United States was 15\% from 2011 to 2014, with stage 3 CKD being the most prevalent (Fig. 1a) [1•]. The prevalence of early CKD is generally similar across races and ethnicities (Fig. 1b). However, the prevalence of ESRD is 3.7 times greater in African Americans, 1.4 times greater in Native Americans, and 1.5 times greater in Asians than in the nonHispanic White population; the prevalence of ESRD is almost $58 \%$ higher among Hispanics compared with non-Hispanics 


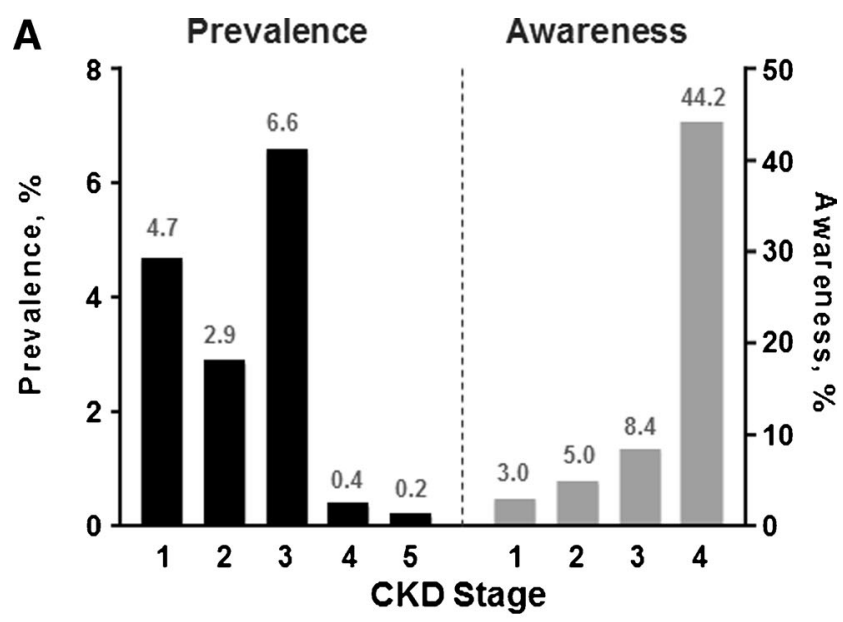

B

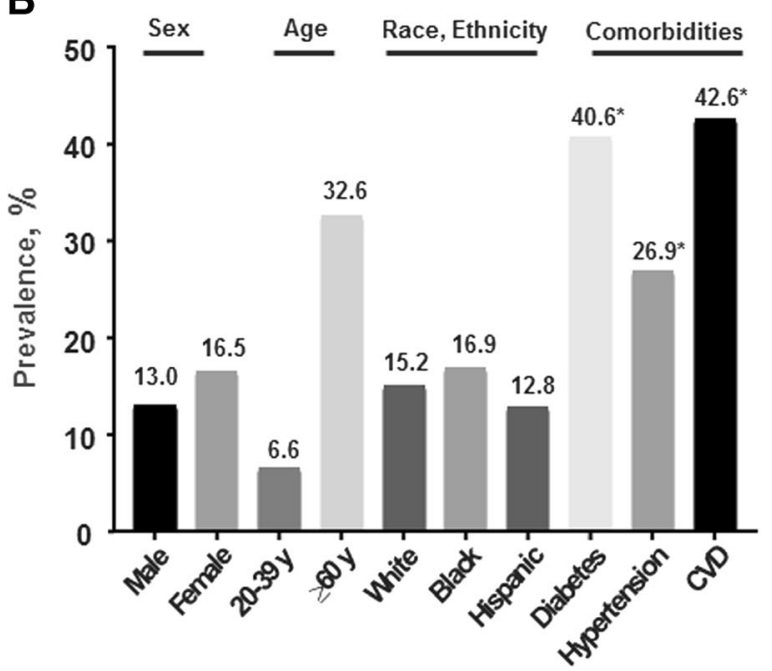

Fig. 1 (a) Prevalence of CKD (2011-2014) and CKD awareness (20092012) by CKD stage in the NHANES population and (b) prevalence of CKD in the NHANES population (2011-2014) within sex, age, race/ethnicity, and risk factor categories. CKD, chronic kidney disease; NHANES, National Health and Nutrition Examination Survey. CKD stage, GFR $\left(\mathrm{mL} / \mathrm{min} / 1.73 \mathrm{~m}^{2}\right): 1,>90 ; 2,60-89 ; 3,30-59 ; 4,15-29$; $5,<15$. *Self-reported. (Data from the United States Renal Data System. 2016 USRDS annual data report: epidemiology of kidney disease in the United States. National Institutes of Health, National Institute of Diabetes and Digestive and Kidney Diseases, Bethesda, MD, 2016 [1•]. The data reported here have been supplied by the United States Renal Data System (USRDS). The interpretation and reporting of these data are the responsibility of the authors and in no way should be seen as an official policy or interpretation of the US government.)

[1•]. The prevalence of CKD is slightly higher in women compared with men and increases with age (Fig. 1b) [1•]. However, because GFR naturally declines with age, the prevalence of actual kidney disease in the elderly may be overestimated [10, 11].

A key feature of CKD and DKD is a lack of awareness of the disease in both patients (Fig. 1a) and healthcare providers $[1 \bullet, 12]$. In the United States, even in patients with severe (stage 4) CKD, less than half were aware of their kidney damage [12].
The pathophysiology of DKD is typically manifested through damage to the glomerulus, interstitium, and blood vessels. At a given eGFR, higher levels of albuminuria, which are typically observed in DKD, are associated with accelerated progression to ESRD and/or decreased life expectancy [13, 14]. However, not all patients with DKD and reduced eGFR have increased albuminuria $[15,16]$, and some patients with albuminuria $<300 \mathrm{mg} / \mathrm{mL}$ ( $21 \%$ to $64 \%)$ may return to normal albumin excretion [17].

In addition to higher rates of ESRD, individuals with diabetes have an increased risk of mortality, mainly from cardiovascular disease (CVD) [18], which is strongly associated with DKD. These complications underscore the importance of screening, early detection, and treatment of DKD. Better awareness and early identification of DKD and addressing risk factors for DKD may directly impact the development and progression of the disease, helping to reduce morbidity and mortality. This review has two objectives. The first is to identify population characteristics of important risk factors for the development and progression of DKD in the United States. Second, we discuss barriers and opportunities to improve awareness, management, and outcomes in patients with DKD.

\section{Search Strategy}

References for this review were identified through a search of PubMed for English language articles published from January 2011 to August 2017 by use of the term "diabetic kidney disease" alone and in combination with "progression" and "risk factors." Articles pertaining to CKD and DKD epidemiology, management, albuminuria, socioeconomic factors, and patient/physician education and awareness were retrieved and reviewed. Relevant references cited in retrieved articles were also reviewed. Note, in this review, the terms African American, Black, and Non-Hispanic Black are used interchangeably based on how persons were characterized in the literature. The same holds true for the terms Hispanic and Latino.

\section{Consequences of CKD and DKD}

In patients with CKD, the rate of decline in GFR is variable [19], and the rate of progression to ESRD and renal replacement therapy is influenced by multiple factors. Therefore, slowing the rate of progression of CKD is a priority. In an analysis of patients with CKD in a large managed healthcare organization, the proportion of patients with CKD who progressed to dialysis over a 5 -year period was $1 \%, 1 \%$, and $20 \%$ for CKD stages 2,3, and 4, respectively. Mortality rates over this period were $20 \%, 24 \%$, and $46 \%$ for CKD stages 2 , 3 , and 4, respectively [20]. Factors associated with a more 
rapid decline in GFR included lower serum albumin and lower hemoglobin, higher glycated hemoglobin (HbAlc), higher albuminuria, elevated blood pressure, low physical activity, and black race [19, 21, 22]. In The United Kingdom Prospective Diabetes Study of 5102 patients with newly diagnosed T2DM, 0.3\%/year of patients with albuminuria 50-299 $\mathrm{mg} / \mathrm{L}$ and $2 \% /$ year with albuminuria $\geq 300 \mathrm{mg} / \mathrm{L}$ progressed to ESRD over a median follow-up of 10.4 years [23]. Of note, $3 \% /$ year and $5 \% /$ year, respectively, died during this period. Thus, in patients with DKD, death is more likely than renal replacement therapy.

Chronic kidney disease is often asymptomatic, especially in its early stages. Yet, the risk for CVD is increased even in individuals with stages 1-2 CKD compared with those without CKD [24]. In an analysis of patients $(N=266,975)$ at high risk for CKD (e.g., those with hypertension, diabetes, or CVD), there was a graded and independent increased risk for all-cause and cardiovascular mortality with increasing albuminuria and decreasing eGFR below $60 \mathrm{~mL} / \mathrm{min} /$ $1.73 \mathrm{~m}^{2}$ [25]. Other studies in patients with diabetes have also found that increased albuminuria and decreased eGFR are independent risk factors for cardiovascular mortality, cardiovascular events, and renal events, including progression to ESRD [26].

\section{Factors Contributing to DKD}

Improved communication with patients of the importance of risk factors associated with diabetes and DKD may improve management of the risk factors and the clinical outcomes. In the United States, the high prevalence of obesity $(35 \%)$ [27] and metabolic syndrome (33\%) [28] (three or more of increased waist circumference, hypertension, insulin resistance, or dyslipidemia) are among the major factors that contribute to the high prevalence of T2DM. Hyperglycemia and the common comorbidities of hypertension and dyslipidemia in patients with T2DM are among the major risk factors for the development and progression of DKD [29] (see Supplemental text).

The need to treat multiple risk factors increases the challenge of controlling DKD progression. An analysis of the NHANES database (2007-2010) found that only 52\% of adults with diagnosed diabetes achieved $\mathrm{HbAlc}<7 \%, 51 \%$ achieved blood pressure $<130 / 80 \mathrm{mmHg}$, and approximately $56 \%$ achieved LDL cholesterol $<100 \mathrm{mg} / \mathrm{dL}$ [30, 31]. However, the most striking feature of this analysis was that only $19 \%$ of patients achieved all three of these goals.

A more detailed discussion of these and other risk factors can be found in the online Supplement. Guidelines for target levels and treatment are briefly outlined here and in Supplemental Table 1.

\section{Hyperglycemia}

Results from the Diabetes Control and Complications Trial (DCCT) [32] and its long-term follow-up study, Epidemiology of Diabetes Interventions and Complications (EDIC) [33] in patients with type 1 diabetes, suggested that intensive glycemic control (target HbA1c $<6 \%$ ), especially early in the disease course, reduced the risk of microvascular and, to some extent, macrovascular complications and mortality. Conflicting results were observed in the Action to Control Cardiovascular Risk in Diabetes (ACCORD) trial [34], the Veterans Affairs Diabetes Trial (VADT) [35], and the Action in Diabetes and Vascular Disease: Preterax and Diamicron Modified-Release Controlled Evaluation (ADVANCE) trial [36], in which intensive glycemic control resulted in little or no significant reductions in $\mathrm{CV}$ outcomes in patients with T2DM and established CV disease and/or multiple CV risk factors. In ACCORD, intensive glycemic control (target HbA1c $<6 \%$ ) compared with standard therapy (target HbA1c $7.0 \%-7.9 \%$ ) was associated with an increase in mortality [34]. Subsequent analysis suggested that severe hypoglycemia was associated with an increased risk of death in both the intensive and standard therapy treatment arms of the ACCORD study [37]. Based on these studies, the American Diabetes Association (ADA) recommends that treatment goals for hyperglycemia should be individualized based on diabetes duration, life expectancy, comorbidities, risk for hypoglycemia, and patient preferences [8, 38 ] and target an $\mathrm{HbAlc}$ of $7 \%$ or lower in most patients $[38,39]$. Among individuals with DKD, there is some evidence for a U-shaped relationship between HbA1c and mortality with the risk of death increasing with HbA1c < $6.5 \%$ and $>8 \%$. Thus, a target $\mathrm{HbAlc}$ of $\sim 7 \%$ is recommended for patients with DKD $[8,38]$. Among older adults on antihyperglycemic agents, lower eGFR is associated with increased incidence of hospital encounters for hypoglycemia [40].

\section{Hypertension}

The ADA recommends target blood pressure $<140 /$ $90 \mathrm{mmHg}$ for most patients with diabetes [8, 41•], and the Kidney Disease Outcomes Quality Initiative (KDOQI) guidelines recommend $<130 / 80 \mathrm{mmHg}$ for patients with DKD [6]. The recent 2017 American College of Cardiology/American Heart Association Task Force on Clinical Practice Guidelines also recommends a target blood pressure $<130 / 80 \mathrm{mmHg}$ [42•]. In patients with DKD and hypertension, angiotensin-converting enzyme inhibitors (ACEIs) and angiotensin II receptor blockers (ARBs) are the recommended first-line agents for blood pressure control $[6,8]$. 


\section{Dyslipidemia}

Lipid abnormalities are common in patients with diabetes and typically include elevated triglycerides, reduced high-density lipoprotein (HDL) cholesterol, and elevated low-density lipoprotein (LDL) cholesterol [43]. Although specific lipid target levels are not specified, treatment guidelines recommend the use of statins to reduce the risk of cardiovascular events in patients with DKD (but not those on dialysis) [44].

\section{Albuminuria}

Albuminuria is both a marker of kidney disease and a risk factor for CKD progression and cardiovascular events [7]. It is important to note that there is a graded association of albuminuria and risk for progression to ESRD, CVD, or death with increasing risk as levels of albuminuria rise $[25,38,45,46]$.

\section{Diagnosis of DKD}

As noted earlier, DKD is commonly diagnosed by an eGFR $<60 \mathrm{~mL} / \mathrm{min} / 1.73 \mathrm{~m}^{2}$ and/or albuminuria $>30 \mathrm{mg} / \mathrm{g}$ creatinine in the presence of longstanding diabetes and no other causes of CKD [7, 8]. However, some patients with diabetes develop DKD without an increase in urinary protein excretion, whereas remission to normal protein excretion has been reported in some patients with DKD [17]. Therefore, whether or not moderate levels of albuminuria by itself are an early predictor of DKD and its progression remains controversial [17, $47,48]$. This may be due to multiple pathophysiological factors which are part of the constellation of DKD (interstitial damage, vascular and/or glomerular) [49] and reinforces the need to search for more sensitive and specific biomarkers [50, 51]. Nevertheless, albuminuria, together with eGFR, remains useful for monitoring kidney function $[38,52]$. The current lack of awareness of the significance of DKD has contributed to underuse of these diagnostic tools. A summary of the current state of screening for reduced kidney function may be found in the Supplement.

\section{Barriers to DKD Management}

A key problem associated with CKD and DKD is a lack of awareness of the disease (Fig. 1a).

Effective management of DKD is multidisciplinary and requires heightened awareness of DKD by healthcare providers and patients as well as effective communication and collaboration between healthcare providers, specialists, and their patients. Additional barriers exist affecting the successful management of DKD, including socioeconomic factors, access to healthcare and health insurance, and education and awareness of DKD. Unfortunately, populations at highest risk of T2DM, DKD, and ESRD (e.g., African Americans, Native Americans, Hispanic/Mexican Americans, and those with low socioeconomic status) $[1 \bullet, 4]$ are also those that have the most barriers to overcome in accessing quality healthcare $[53,54]$. Figure 2 presents a summary of some of the barriers to effective care and opportunities for minimizing those barriers.

\section{Patient-Specific Barriers}

\section{DKD Awareness}

Data related to patient-specific barriers for DKD are limited; thus, we present data for overall CKD, recognizing that these data should be applicable to DKD as well. Data supporting the discussion of patient-specific barriers can be found in Supplemental Table 2. Awareness of CKD in general and DKD in particular is low in the United States (Fig. 1a) $[1 \bullet$, 55] and globally [56•]. Patient awareness of CKD is low at all stages of CKD, even stage 4 [55], but does increase with the severity of CKD $[57,58]$, in the presence of or risk for comorbidities (e.g., diabetes, hypertension, obesity, CVD) [56•, 57-59], and increasing laboratory markers of CKD complications (e.g., albuminuria, hyperkalemia, hypophosphatemia, anemia, acidosis, elevated blood urea nitrogen) [60].

The greater awareness of CKD among men may be because men normally have higher serum creatinine than women, and physicians may view them as being at higher risk for CKD than women [57]. However, this could also reflect provider biases in patient communication. A greater awareness among African Americans than non-Hispanic White or Mexican Americans may be due to increased recognition by African Americans and their physicians of race as a powerful risk factor for ESRD, and/or the greater family history of $\mathrm{CKD} / \mathrm{ESRD}$ in this population [57].

\section{Education and Socioeconomic Status}

Both the extent of educational attainment and socioeconomic status have been shown to be associated with barriers to care in CKD patients. A variety of studies have demonstrated that income and level of education are associated with risk factors for and progression of CKD [61, 62]. Because level of education and socioeconomic status are not uniformly distributed across ethnic groups, the effects of limited education and socioeconomic status are more acute in racial and ethnic minority populations.

\section{Healthcare Literacy}

In general, poor health literacy (skills needed to function effectively in the healthcare environment) is associated with 
Fig. 2 Barriers to care and opportunities to improve awareness, management, and outcomes in patients with DKD

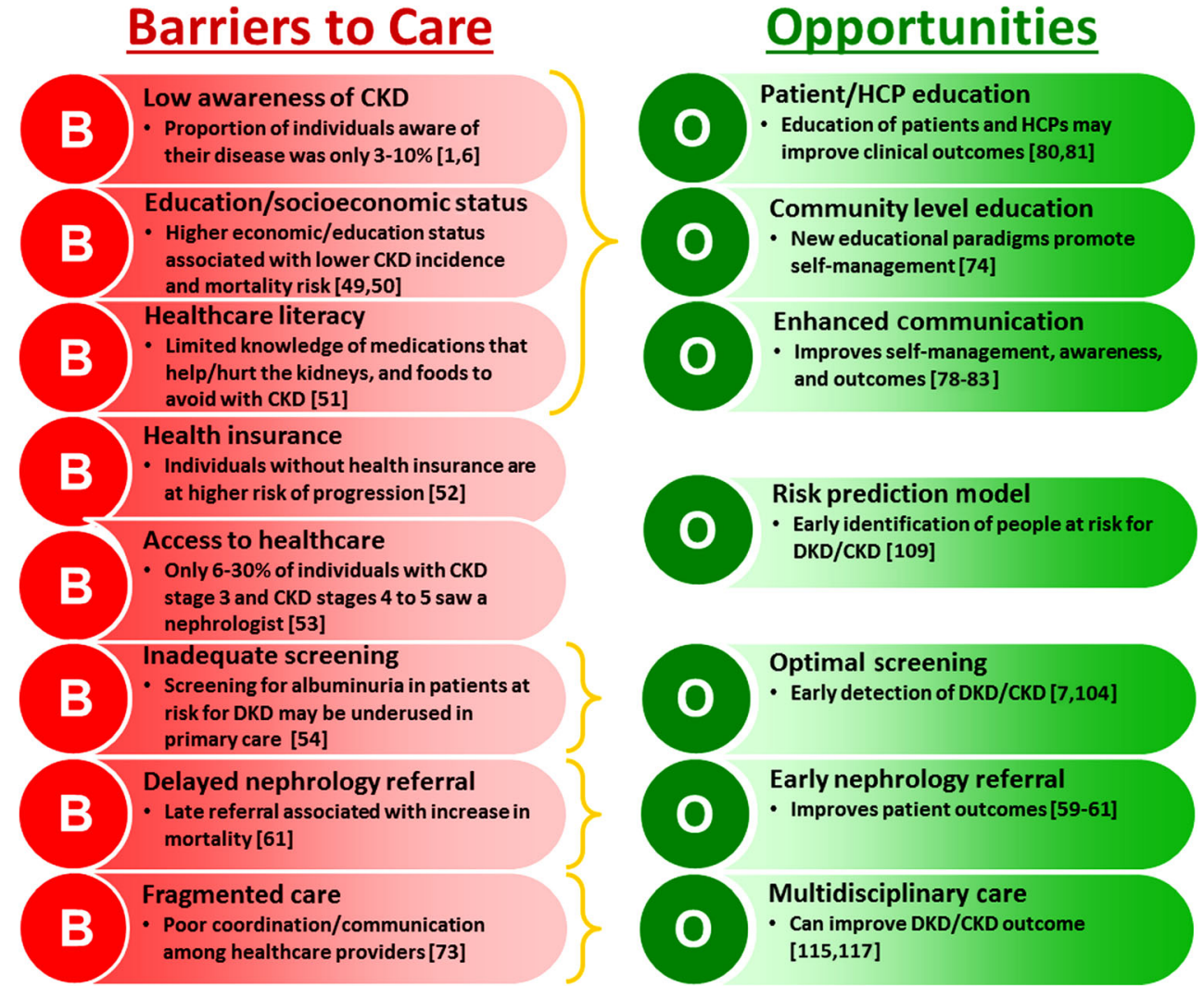

more hospitalizations and emergency room use, lower use of preventative services, and poorer adherence to medications, and may partially explain racial disparities in healthcare service utilization and outcomes [63].

\section{Access to Health Insurance and Healthcare}

In the United States, individuals with CKD and no health insurance were less likely to receive treatment for risk factors associated with the progression of CKD, such as hypertension, diabetes, and obesity, than individuals with CKD and health insurance [64]. A smaller proportion of African American and Hispanic individuals with CKD reported having a physician than non-Hispanic White individuals [65].

\section{Provider-Specific Barriers}

\section{DKD Awareness}

Primary care physicians appear to have a low awareness of CKD and DKD. In a multicenter observational study in 466 primary care practices, only $47 \%$ of primary care providers (PCPs) identified CKD in their patients with T2DM, primarily because of underutilization of screening assessments, such as urinary albumin/protein excretion [12]. Importantly, patient awareness of DKD was
$81 \%$ in patients in whom a PCP diagnosed DKD compared with only $3 \%$ in the absence of a DKD diagnosis, suggesting a link between clinician diagnosis of DKD and patient awareness [12]. Data supporting the discussion of provider-specific barriers can be found in Supplemental Table 3.

Some studies suggest that screening for albuminuria in patients at risk for DKD may be underused in primary care [12, 66]. Unsurprisingly, family practice physicians and general internists were less aware of clinical practice guidelines for CKD than nephrologists [67]. Furthermore, in another survey conducted in predominantly African American communities, most PCPs recognized diabetes and hypertension as risk factors for CKD; however, $34 \%$ did not consider family history of CKD, and $22 \%$ did not consider race as a risk factor for CKD [68].

\section{Contact Time and Communication with Patient}

Diabetes care professionals commonly cite lack of available time as a barrier for effective communication with patients [69]. The introduction of electronic health records (EHR) has led to physicians spending almost $2 \mathrm{~h}$ on computer and clerical work for every hour they spend with patients [70]. Unfortunately, this is likely to worsen before it becomes better. 


\section{Need for Early Referral to a Nephrologist}

In a prospective cohort study of patients from primary care, referral of patients with T2DM and early DKD (defined as albuminuria $30-300 \mathrm{mg} / \mathrm{g}$ creatinine or eGFR $60-89 \mathrm{~mL} /$ $\min / 1.73 \mathrm{~m}^{2}$ ) to a nephrologist was associated with better preservation of renal function and better control of blood pressure, when compared with continued treatment by PCPs alone [71]. Additional studies have shown that referral of patients with CKD to nephrologists slows the decline in GFR and reduces mortality $[72,73]$.

The finding that nephrologists deliver better CKD-related care to patients with early CKD than PCPs is not unexpected, but there is not a sufficient nephrology workforce in the United States [74] and globally [75] to care for all patients with CKD, and there are many other aspects of total patient care that PCPs do better than nephrologists. Therefore, on balance, education on occasional early consultation for diagnosis and treatment, and timely referral for management support in all patients with advanced CKD stages is critical. Recently, a panel of internists and nephrologists developed a practical approach for the Kidney Disease Outcomes Quality Initiative and recommended referral to nephrology specialists when eGFR fell below $30 \mathrm{~mL} / \mathrm{min} / 1.73 \mathrm{~m}^{2}$, or for severe albuminuria ( $\geq 300 \mathrm{mg} / \mathrm{g}$ creatinine) [76] or acute kidney injury $[76,77]$.

The critical need for referral is further highlighted by a report from Gillespie et al. [78] who examined Medicare data from 2006 to 2010 and found that $33 \%$ of patients received no nephrology care before the onset of ESRD. According to an analysis of the USRDS database (2007-2012), poverty, African American race, and Hispanic ethnicity were independently associated with lower rates of pre-ESRD nephrology care [79].

\section{Treatment-Specific Barriers}

Treatment of diabetes and CKD is complex, both for the provider and patient. Clinical inertia, or the failure to intensify treatment when a patient is not at recommended goals, is of particular concern. In a retrospective analysis of people with T2DM, some patients remained in poor glycemic control for up to 7 years before intensification of treatment [80]. Similarly, in an analysis of patients with CKD and uncontrolled hypertension, the prevalence of clinical inertia was $44 \%$ [81]. Moreover, certain classes of medications, such as ACEIs, ARBs, and statins, may be underutilized in patients with CKD and comorbidities [82].

Patients with CKD usually have multiple comorbidities and may be prescribed more than 20 medications [82]. Thus, suboptimal medication adherence represents a substantial barrier to effective management of CKD. In a study of patients with CKD and hypertension, only two thirds (69\%) of patients reported appropriate medication adherence; older age and higher income were associated with higher adherence [83]. However, it should also be noted that patient self-reporting may overestimate medication adherence [84].

\section{Health System-Specific Barriers}

The first barrier to overcome for optimal DKD care is to ensure the understanding of the significance and limitations of appropriate laboratory testing [85]. Additional health system barriers include poor coordination of a broad range of providers across diverse settings, including inpatient and outpatient facilities, emergency departments, pharmacies, and dialysis facilities, that limit the provision of accurate and timely information [86]. The introduction of EHRs addresses some but not all of the barriers of a distributed healthcare system because many system components do not interact [86]. Other factors such as delivery system design, provider decision support tools, integration of kidney disease management into existing diabetes care processes, and the creation of "medical neighborhoods" formed through accountable care organizations are also needed to improve CKD care [86, 87].

\section{Community-Specific Barriers}

Multiple barriers to DKD care exist at the community level, especially in high-risk communities, and include low health literacy, being un- or under-insured, difficulty in accessing quality care, limited availability of CKD information, lack of readiness to learn, lack of trust in the health system, and other factors [54, 88, 89]. Recent approaches using new educational paradigms and new groups of health professionals have demonstrated great potential to promote self-management, and others should be considered, such as the use of lay health educators and engagement of community-based and allied health professionals in early CKD management [87]. Family or close friend/confidant-based interventions can assist in implementing and increasing adherence to lifestyle, nutritional, and pharmacologic interventions [87]. Because health literacy, educational attainment, and cultural beliefs and behaviors vary widely across different communities, efforts to adapt and assess the effectiveness of many existing educational materials to address the needs of diverse populations with CKD or the use of novel strategies such as social or digital media are needed $[87,88,90]$.

\section{Recommendations for Better DKD Management}

\section{Patient and Physician Education}

The reviewed literature herein suggests that patients' and healthcare providers' knowledge and awareness of CKD and 
DKD can be improved. Many patients with CKD or ESRD do not feel engaged (limited knowledge of their disease, complex treatments), and many do not receive patient-centered care [91]. Healthcare providers may not recognize CKD in its early stages and may not be familiar with clinical practice guidelines or recommendations [67].

Educational efforts aimed at patients and healthcare providers have been shown to improve clinical outcomes. For example, brief physician-led educational discussions with patients improve their CKD awareness and understanding of the severity of their disease [92]. Many patients want to be educated about CKD [88], which may improve blood pressure [93, 94], lengthen time to dialysis/transplantation [95], and improve survival $[93,94]$. Educating individuals with progressive CKD about kidney function, kidney disease, diet, and lifestyle changes delayed the initiation of dialysis [95] and prolonged survival [94]. Moreover, in patients with diabetes, training sessions about health literacy and numeracy were associated with better glycemic control and diabetes self-management compared with patients who did not receive such training [96]. Similarly, in a Canadian study of targeted screening for CKD [97], in which individual counseling was provided for those at risk for CKD, most participants $(90 \%)$ reported health behavior changes in a post-screening survey, including dietary changes $(80 \%)$, better adherence to recommendations from their healthcare providers (66\%), and making lifestyle changes (increasing activity, reducing stress, or weight loss) (76\%).

The burden of PCP workload superimposed with patient struggles with inadequate health literacy, coping with new diagnoses, and implications of a possible poor prognosis conspire to limit effective communication. There are tools currently available to help foster such communication. Educational programs are available for patients (National Kidney Disease Education Program) [98], and they are a covered benefit under Medicare for patients with stage $4 \mathrm{CKD}$ [99]. A multidimensional support program (disease knowledge, self-management, and motivation skills) has been shown to improve HbA1c levels, albuminuria, and physical activity in patients with DKD [100]. CKD educational tools for physicians are available from various organizations, including the National Kidney Foundation [101], the Medical Education Institute [102], and the Renal Physicians Association [103].

\section{Optimal Screening}

The United States Preventative Services Task Force concluded that there was insufficient evidence to assess the benefits and harms of screening for CKD in asymptomatic adults [104]. By contrast the American College of Physicians recommends against screening for CKD in asymptomatic adults without risk factors for CKD [105], while the American
Society of Nephrology recommends that all adults undergo screening for CKD [106].

Concerns about total population screening include inappropriate disease labeling impacting insurability as well as falsepositive results with attendant unnecessary testing and treatment. Also, false-negative results create an unwarranted sense of assurance and can delay needed interventions when the actual disease is present [104, 105].

Modeling and other studies have generally found that screening for CKD may be cost-effective only in nonHispanic Blacks [107] or in older patients with diabetes and/ or hypertension or at longer intervals of 5-10 years [108-110]. However, a recent simulation study using CKD risk scores based on diabetes, hypertension, anemia, and CVD suggested that CKD screening may be cost-effective in a broader population [111]. To our knowledge, no randomized trials have evaluated the effectiveness of screening for CKD to improve patient care or outcomes.

Current guidelines from the ADA [112] and the National Kidney Foundation [6] recommend that patients with T2DM be screened annually for albuminuria and eGFR (Supplemental Table 4). Albuminuria in the range of 30 $300 \mathrm{mg} / \mathrm{g}$ creatinine is best measured by a spot urine sample from the first morning void and should be confirmed with two additional measurements during the next 3 to 6 months [6]. If an albuminuria test is not available, a reagent strip may be used [6], preferably a more sensitive strip that can detect lower levels of albuminuria. The use of select microalbuminuria detection strips can provide results similar to the actual albumin:creatinine ratio [113]. In primary care settings, improved screening rates for microalbuminuria in patients with diabetes can be achieved by quality improvement processes that include education of staff on clinical practice guidelines [66]. In addition to diabetes, population characteristics of persons at increased risk for whom screening for CKD should be considered include those with hypertension, family history of CKD, low socioeconomic status, the elderly, and high-risk racial/ethnic groups [54, 114-119].

In patients with known DKD, eGFR should be monitored more frequently; every 6 months if eGFR is $45-60 \mathrm{~mL} / \mathrm{min} /$ $1.73 \mathrm{~m}^{2}$ and every 3 months if eGFR is $30-44 \mathrm{~mL} / \mathrm{min} /$ $1.73 \mathrm{~m}^{2}$ [8]. Serum creatinine can be measured in a spot blood sample and eGFR estimated using various equations [120] either by a clinical laboratory or by online eGFR calculators [66], although most clinical labs now automatically report eGFR compared with less than $50 \%$ only 10 years ago [121].

\section{Risk Prediction Models}

Early detection and treatment of DKD delays progression to ESRD [122]. Methods to identify individuals at risk for developing DKD or at risk for progression to ESRD are important because most patients with DKD are initially identified by 
their PCPs [123]. A number of models have been developed and validated that predict the risk for the development and/or progression of CKD and DKD using readily available laboratory values, such as eGFR, urinary albumin excretion, and blood pressure, as well as age, sex, diabetes status, and ethnicity [124]. Overall, the most predictive variables appear to be eGFR and urinary albumin excretion [125-127]. The development of renal risk scores is still in an early stage, and most models have limitations [123, 124]. Additional research focused on identification and validation of novel biomarkers for DKD prediction is ongoing [128, 129].

\section{Multidisciplinary Care}

Owing to the complex nature of DKD and associated comorbidities, the care of patients with DKD is often divided among PCPs, specialists, nurses, and other healthcare providers. Multidisciplinary care consisting of an integrated team of physicians, nurses, dietitians, and educators has been shown to slow the decline in kidney function and the progression to ESRD [130]. For example, in a group of patients with stage 3 CKD and diabetes and/or hypertension, multidisciplinary care with a team composed of a PCP, nephrologist, pharmacy specialist, diabetes educator, dietitian, social worker, and nephrology nurse resulted in an annual decline in eGFR that was approximately half of that observed in patients with usual care (a PCP and nephrologist referral) [131]. In another study of patients with stages 3-5 CKD (44\% with diabetes), multidisciplinary care slowed eGFR decline, decreased cardiovascular events and infections, reduced the need for renal replacement therapy, and was more cost-effective than usual care (nephrology outpatient clinic) [132].

As noted earlier, a multidimensional educational support program can improve HbA1c levels, albuminuria, and physical activity in patients with DKD [100]. Similarly, intensive management of patients with diabetes consisting of online health coaching, individualized nutrition education to reduce carbohydrate intake, and behavioral support for 10 weeks improved glycemic control, enhanced weight loss, and reduced the number and/or dosage of antidiabetes medications [133]. Remotely delivered intensive behavioral counseling programs may also be effective and have been associated with considerably reduced medical expenditures [134].

Treatment guidelines and pharmacotherapy recommendations for diabetes, DKD, and CKD are beyond the scope of this review but can be found in publications from the ADA [112] and National Kidney Foundation $[6,38,39,135 \cdot \bullet]$. It appears, however, that multifactorial and multidisciplinary intervention targeting multiple risk factors may provide better patient outcomes. For example, in the STENO-2 trial in patients with T2DM, diet and exercise together with therapy targeting hyperglycemia, hypertension, and dyslipidemia; smoking cessation; aspirin; and antioxidants significantly reduced the risk for the development of nephropathy compared with conventional therapy [136]. After 21 years of follow-up, the multifactorial therapy group had reduced progression to macroalbuminuria, a slower rate of decline in eGFR, and a trend toward less progression to ESRD compared with the conventional therapy group $[137 \bullet \bullet]$.

\section{Conclusion}

Diabetic kidney disease remains a major healthcare issue. Awareness of DKD is low among both patients and their healthcare providers. Although many barriers exist, diagnostic tools needed to increase awareness are readily available, and programs that increase disease awareness have been demonstrated to be both clinically effective and effective in reducing the use of healthcare resources. DKD disproportionately affects minorities, and those with more limited education, lower socioeconomic status, and reduced access to healthcare and health insurance. Progressive policy changes are needed to address these social determinants of health.

\section{Strategies to Improve DKD Outcomes}

Given the strong association of increasing levels of albuminuria and clinical outcomes, albuminuria should be reported as a continuous variable, rather than the more limited terms microalbuminuria and macroalbuminuria. This will promote more attention at the health system and provider levels to each patient's risk status and can help to guide response to therapy. Novel strategies to improve DKD outcomes (Table 1, Fig. 2) include improved targeting of high-risk patients and enhanced communication and education through the use of telehealth technology to both obtain patients' vital signs and deliver kidney health services to expand choice, facilitate access to care, and deliver patient-centered kidney specialty care services and education via synchronous and asynchronous approaches [138]. Improved delivery of quality healthcare can be facilitated by the use of CKD clinical decision support tools to promote timely referral [139], provider incentives, interdisciplinary care models [88], and the use of CKD patient navigators, especially for those with advanced disease and approaching ESRD to help coordinate care, address system barriers, and educate/motivate patients [140]. Additional 
Table 1 Strategies to improve diabetic kidney disease outcomes: a call to action

\begin{tabular}{|c|c|c|}
\hline $\begin{array}{l}\text { Improve targeting of } \\
\text { high-risk patients }\end{array}$ & $\begin{array}{l}\text { Enhance } \\
\text { communication and } \\
\text { education }\end{array}$ & $\begin{array}{l}\text { Improve delivery of } \\
\text { quality healthcare }\end{array}$ \\
\hline $\begin{array}{l}\text { Use of electronic health } \\
\text { records to identify } \\
\text { high-risk persons } \\
\text { and alert providers }\end{array}$ & $\begin{array}{l}\text { Enhanced } \\
\text { patient-centered } \\
\text { approaches }\end{array}$ & $\begin{array}{l}\text { Use of DKD patient } \\
\text { navigators as ESRD } \\
\text { approaches }\end{array}$ \\
\hline $\begin{array}{l}\text { Small area analysis to } \\
\text { identify } \\
\text { communities with } \\
\text { higher rates of } \\
\text { DKD/ESRD }\end{array}$ & $\begin{array}{l}\text { Community-level } \\
\text { education strategies } \\
\text { to increase } \\
\text { awareness of and } \\
\text { impact on DKD risk } \\
\text { factors }\end{array}$ & $\begin{array}{l}\text { Advocacy for } \\
\text { single-payer and/or } \\
\text { disease- } \\
\text { management health } \\
\text { care systems }\end{array}$ \\
\hline $\begin{array}{l}\text { Increased nephrology } \\
\text { referral of patients } \\
\text { with stage } 3 / 4 \text { DKD }\end{array}$ & $\begin{array}{l}\text { Increased patient input } \\
\text { into DKD care } \\
\text { strategies }\end{array}$ & $\begin{array}{l}\text { Increased system leve } \\
\text { support for PCPs }\end{array}$ \\
\hline
\end{tabular}

DKD, diabetic kidney disease; ESRD, end-stage kidney disease; PCP, primary care provider

considerations include promotion of self-management support, shared decision making, use of digital media, and family and community engagement [88]. Finally, promoting policies to support public awareness and patient education programs requires ongoing advocacy.

Acknowledgments The authors thank Emily Chastain of AbbVie for her help in developing figures for this manuscript. Medical writing support was provided by Richard M. Edwards, $\mathrm{PhD}$, and Janet E. Matsuura, $\mathrm{PhD}$, of Complete Publication Solutions, LLC (North Wales, PA), a CHC Group company and was funded by AbbVie.

Author Contribution All authors contributed to the development of the content; all authors and AbbVie reviewed and approved the final submitted version of the manuscript.

Funding Information AbbVie funded this review.

\section{Compliance with Ethical Standards}

Conflict of Interest O. Kenrik Duru declared that he has no conflicts to report.

Tim Middleton and Mona K. Tewari are employees of AbbVie and may hold AbbVie stock and/or stock options.

Keith Norris is a speaker for OPKO and an educational consultant for AbbVie.

Human and Animal Rights and Informed Consent This article does not contain any studies with human or animal subjects performed by any of the authors.

Open Access This article is distributed under the terms of the Creative Commons Attribution 4.0 International License (http:// creativecommons.org/licenses/by/4.0/), which permits unrestricted use, distribution, and reproduction in any medium, provided you give appropriate credit to the original author(s) and the source, provide a link to the Creative Commons license, and indicate if changes were made.

\section{References}

Papers of particular interest, published recently, have been highlighted as:

- Of importance

• Of major importance

1. United States Renal Data System. USRDS annual data report: epidemiology of kidney disease in the United States. Bethesda, MD: National Institutes of Health, National Institute of Diabetes and Digestive and Kidney Diseases; 2017. 2017 [cited 2017 December 7]. Available from: https://www.usrds.org/adr.aspx. Provides up-todate data on the prevalence and awareness of CKD and ESKD in the United States.

2. Jha V, Garcia-Garcia G, Iseki K, Li Z, Naicker S, Plattner B, et al Chronic kidney disease: global dimension and perspectives. Lancet. 2013;382(9888):260-72. https://doi.org/10.1016/S01406736(13)60687-X

3. Centers for Disease Control and Prevention. National Diabetes Statistics Report, 2014. 2014 [cited 2016 December 7]. Available from: http://www.cdc.gov/diabetes/pdfs/data/2014report-estimates-of-diabetes-and-its-burden-in-the-united-states. pdf.

4. Menke A, Casagrande S, Geiss L, Cowie CC. Prevalence of and trends in diabetes among adults in the United States, 1988-2012. JAMA. 2015;314(10):1021-9. https://doi.org/10.1001/jama.2015. 10029.

5. Zelnick LR, Weiss NS, Kestenbaum BR, Robinson-Cohen C, Heagerty PJ, Tuttle K, et al. Diabetes and CKD in the United States population, 2009-2014. Clin J Am Soc Nephrol. 2017. New prevalence data for DKD.

6. National Kidney Foundation. KDOQI clinical practice guidelines and clinical practice recommendations for diabetes and chronic kidney disease. Am J Kidney Dis. 2007;49(suppl 2): s1-s180.

7. Tuttle KR, Bakris GL, Bilous RW, Chiang JL, de Boer IH, Goldstein-Fuchs J, et al. Diabetic kidney disease: a report from an ADA consensus conference. Am J Kidney Dis. 2014;64(4): 510-33. https://doi.org/10.1053/j.ajkd.2014.08.001.

8. American Diabetes Association. 10. Microvascular complications and foot care. Diabetes Care. 2017;40(Suppl 1):S88-98. https:// doi.org/10.2337/dc17-S013.

9. Rowley WR, Bezold C, Arikan Y, Byrne E, Krohe S. Diabetes 2030: insights from yesterday, today, and future trends. Popul Health Manag. 2017;20(1):6-12. https://doi.org/10.1089/pop. 2015.0181.

10. Delanaye P, Glassock RJ, Pottel H, Rule AD. An age-calibrated definition of chronic kidney disease: rationale and benefits. Clin Biochem Rev. 2016;37(1):17-26.

11. Winearls CG, Glassock RJ. Classification of chronic kidney disease in the elderly: pitfalls and errors. Nephron Clin Pract. 2011;119(Suppl 1):c2-4. https://doi.org/10.1159/000328013.

12. Szczech LA, Stewart RC, Su HL, DeLoskey RJ, Astor BC, Fox CH, et al. Primary care detection of chronic kidney disease in adults with type-2 diabetes: the ADD-CKD study (awareness, detection and drug therapy in type 2 diabetes and chronic kidney disease). PLoS One. 2014;9(11):e110535. https://doi.org/10.1371/journal.pone.0110535.

13. Berhane AM, Weil EJ, Knowler WC, Nelson RG, Hanson RL. Albuminuria and estimated glomerular filtration rate as predictors of diabetic end-stage renal disease and death. Clin J Am Soc Nephrol. 2011;6(10):2444-51. https://doi.org/10.2215/CJN.00580111.

14. Turin TC, Ahmed SB, Tonelli M, Manns B, Ravani P, James M, et al. Kidney function, albuminuria and life expectancy. Can J Kidney Health Dis. 2014;1:33. https://doi.org/10.1186/s40697-014-0033-6. 
15. MacIsaac RJ, Tsalamandris C, Panagiotopoulos S, Smith TJ, McNeil KJ, Jerums G. Nonalbuminuric renal insufficiency in type 2 diabetes. Diabetes Care. 2004;27(1):195-200. https://doi.org/ 10.2337/diacare.27.1.195.

16. Molitch ME, Steffes M, Sun W, Rutledge B, Cleary P, de Boer IH, et al. Development and progression of renal insufficiency with and without albuminuria in adults with type 1 diabetes in the diabetes control and complications trial and the epidemiology of diabetes interventions and complications study. Diabetes Care. 2010;33(7): 1536-43. https://doi.org/10.2337/dc09-1098.

17. MacIsaac RJ, Ekinci EI, Jerums G. Progressive diabetic nephropathy. How useful is microalbuminuria?: contra. Kidney Int. 2014;86(1):50-7. https://doi.org/10.1038/ki.2014.98.

18. Emerging Risk Factors Collaboration, Seshasai SR, Kaptoge S, Thompson A, Di Angelantonio E, Gao P, et al. Diabetes mellitus, fasting glucose, and risk of cause-specific death. N Engl J Med. 2011;364(9):829-41. https://doi.org/10.1056/NEJMoa1008862.

19. Rossing K, Christensen PK, Hovind P, Tarnow L, Rossing P, Parving HH. Progression of nephropathy in type 2 diabetic patients. Kidney Int. 2004;66(4):1596-605. https://doi.org/10.1111/ j.1523-1755.2004.00925.x.

20. Keith DS, Nichols GA, Gullion CM, Brown JB, Smith DH. Longitudinal follow-up and outcomes among a population with chronic kidney disease in a large managed care organization. Arch Intern Med. 2004;164(6):659-63. https://doi.org/10.1001/ archinte.164.6.659.

21. Leehey DJ, Kramer HJ, Daoud TM, Chatha MP, Isreb MA. Progression of kidney disease in type 2 diabetes - beyond blood pressure control: an observational study. BMC Nephrol. 2005;6(1):8. https://doi.org/10.1186/1471-2369-6-8.

22. Robinson-Cohen C, Littman AJ, Duncan GE, Weiss NS, Sachs MC, Ruzinski J, et al. Physical activity and change in estimated GFR among persons with CKD. J Am Soc Nephrol. 2014;25(2): 399-406. https://doi.org/10.1681/ASN.2013040392.

23. Adler AI, Stevens RJ, Manley SE, Bilous RW, Cull CA, Holman $\mathrm{RR}$, et al. Development and progression of nephropathy in type 2 diabetes: the United Kingdom Prospective Diabetes Study (UKPDS 64). Kidney Int. 2003;63(1):225-32. https://doi.org/10. 1046/j.1523-1755.2003.00712.x.

24. Di Angelantonio E, Chowdhury R, Sarwar N, Aspelund T, Danesh J, Gudnason V. Chronic kidney disease and risk of major cardiovascular disease and non-vascular mortality: prospective population based cohort study. BMJ. 2010;341(sep30 1):c4986. https:// doi.org/10.1136/bmj.c4986.

25. van der Velde M, Matsushita K, Coresh J, Astor BC, Woodward $\mathrm{M}$, Levey A, et al. Lower estimated glomerular filtration rate and higher albuminuria are associated with all-cause and cardiovascular mortality. A collaborative meta-analysis of high-risk population cohorts. Kidney Int. 2011;79(12):1341-52. https://doi.org/10. 1038/ki.2010.536.

26. Ninomiya T, Perkovic V, de Galan BE, Zoungas S, Pillai A, Jardine M, et al. Albuminuria and kidney function independently predict cardiovascular and renal outcomes in diabetes. J Am Soc Nephrol. 2009;20(8):1813-21. https://doi.org/10.1681/ASN. 2008121270.

27. Ogden CL, Carroll MD, Kit BK, Flegal KM. Prevalence of childhood and adult obesity in the United States, 2011-2012. JAMA. 2014;311(8):806-14. https://doi.org/10.1001/jama.2014.732.

28. Aguilar M, Bhuket T, Torres S, Liu B, Wong RJ. Prevalence of the metabolic syndrome in the United States, 2003-2012. JAMA. 2015;313(19):1973-4. https://doi.org/10.1001/jama.2015.4260.

29. Retnakaran R, Cull CA, Thorne KI, Adler AI, Holman RR, Group US. Risk factors for renal dysfunction in type 2 diabetes: U.K. prospective diabetes study 74. Diabetes. 2006;55(6):1832-9. https://doi.org/10.2337/db05-1620.
30. Ali MK, Bullard KM, Saaddine JB, Cowie CC, Imperatore G, Gregg EW. Achievement of goals in U.S. diabetes care, 19992010. N Engl J Med. 2013;368(17):1613-24. https://doi.org/10. 1056/NEJMsa1213829.

31. Stark Casagrande S, Fradkin JE, Saydah SH, Rust KF, Cowie CC. The prevalence of meeting A1C, blood pressure, and LDL goals among people with diabetes, 1988-2010. Diabetes Care. 2013;36(8):2271-9. https://doi.org/10.2337/dc12-2258.

32. Diabetes Control Complications Trial Research Group, Nathan DM, Genuth S, Lachin J, Cleary P, Crofford O, et al. The effect of intensive treatment of diabetes on the development and progression of long-term complications in insulin-dependent diabetes mellitus. N Engl J Med. 1993;329(14):977-86.

33. Nathan DM, Cleary PA, Backlund JY, Genuth SM, Lachin JM, Orchard TJ, et al. Intensive diabetes treatment and cardiovascular disease in patients with type 1 diabetes. N Engl J Med. 2005;353(25):2643-53. https://doi.org/10.1056/NEJMoa052187.

34. Action to Control Cardiovascular Risk in Diabetes Study Group, Gerstein HC, Miller ME, Byington RP, Goff DC Jr, Bigger JT, et al. Effects of intensive glucose lowering in type 2 diabetes. $\mathrm{N}$ Engl J Med. 2008;358(24):2545-59.

35. Duckworth W, Abraira C, Moritz T, Reda D, Emanuele N, Reaven PD, et al. Glucose control and vascular complications in veterans with type 2 diabetes. N Engl J Med. 2009;360(2):129-39. https:// doi.org/10.1056/NEJMoa0808431.

36. Advance Collaborative Group, Patel A, MacMahon S, Chalmers $\mathrm{J}$, Neal B, Billot L, et al. Intensive blood glucose control and vascular outcomes in patients with type 2 diabetes. $\mathrm{N}$ Engl $\mathrm{J}$ Med. 2008;358(24):2560-72.

37. Bonds DE, Miller ME, Bergenstal RM, Buse JB, Byington RP, Cutler JA, et al. The association between symptomatic, severe hypoglycaemia and mortality in type 2 diabetes: retrospective epidemiological analysis of the ACCORD study. BMJ. 2010;340(jan08 1):b4909. https://doi.org/10.1136/bmj.b4909.

38. National Kidney Foundation. KDOQI clinical practice guideline for diabetes and CKD: 2012 update. Am J Kidney Dis. 2012;60(5):850-86.

39. Begun A, Icks A, Waldeyer R, Landwehr S, Koch M, Giani G. Identification of a multistate continuous-time nonhomogeneous Markov chain model for patients with decreased renal function. Med Decis Mak. 2013;33(2):298-306. https://doi.org/10.1177/ 0272989X12466731.

40. Hodge M, McArthur E, Garg AX, Tangri N, Clemens KK. Hypoglycemia incidence in older adults by estimated GFR. Am J Kidney Dis. 2017;70(1):59-68. https://doi.org/10.1053/j.ajkd. 2016.11.019.

41. de Boer IH, Bangalore S, Benetos A, Davis AM, Michos ED, Muntner P, et al. Diabetes and hypertension: a position statement by the American Diabetes Association. Diabetes Care. 2017;40(9):1273-84. https://doi.org/10.2337/dci17-0026. Current recommendations for blood pressure control in diabetes.

42. Whelton PK, Carey RM, Aronow WS, Casey DE, Jr., Collins KJ, Dennison Himmelfarb C, et al. ACC/AHA/AAPA/ABC/ACPM/ AGS/APhA/ASH/ASPC/NMA/PCNA guideline for the prevention, detection, evaluation, and management of high blood pressure in adults: a report of the American College of Cardiology/ American Heart Association Task Force on Clinical Practice Guidelines. J Am Coll Cardiol. 2017. Current recommendations for blood pressure control in diabetes.

43. Krauss RM. Lipids and lipoproteins in patients with type 2 diabetes. Diabetes Care. 2004;27(6):1496-504. https://doi.org/10.2337/ diacare.27.6.1496.

44. KDIGO. Clinical practice guidelines for lipid management in chronic kidney disease. Kidney Int Suppl. 2013;3(3):271-9. 
45. Astor BC, Matsushita K, Gansevoort RT, van der Velde M, Woodward M, Levey AS, et al. Lower estimated glomerular filtration rate and higher albuminuria are associated with mortality and end-stage renal disease. A collaborative meta-analysis of kidney disease population cohorts. Kidney Int. 2011;79(12):133140. https://doi.org/10.1038/ki.2010.550.

46. Amin AP, Whaley-Connell AT, Li S, Chen SC, McCullough PA, Kosiborod MN, et al. The synergistic relationship between estimated GFR and microalbuminuria in predicting long-term progression to ESRD or death in patients with diabetes: results from the Kidney Early Evaluation Program (KEEP). Am J Kidney Dis. 2013;61(4 Suppl 2):S12-23. https://doi.org/10.1053/j.ajkd.2013.01.005.

47. Bakris GL, Molitch M. Microalbuminuria as a risk predictor in diabetes: the continuing saga. Diabetes Care. 2014;37(3):867-75. https://doi.org/10.2337/dc13-1870.

48. Roscioni SS, Lambers Heerspink HJ, de Zeeuw D. Microalbuminuria: target for renoprotective therapy PRO. Kidney Int. 2014;86(1):40-9. https://doi.org/10.1038/ki.2013. 490.

49. Lopez-Novoa JM, Rodriguez-Pena AB, Ortiz A, MartinezSalgado C, Lopez Hernandez FJ. Etiopathology of chronic tubular, glomerular and renovascular nephropathies: clinical implications. J Transl Med. 2011;9(1):13. https://doi.org/10.1186/14795876-9-13.

50. Langsford D, Tang M, Cheikh Hassan HI, Djurdjev O, Sood MM, Levin A. The association between biomarker profiles, etiology of chronic kidney disease, and mortality. Am J Nephrol. 2017;45(3): 226-34. https://doi.org/10.1159/000454991.

51. Sun J, Axelsson J, Machowska A, Heimburger O, Barany P, Lindholm B, et al. Biomarkers of cardiovascular disease and mortality risk in patients with advanced CKD. Clin J Am Soc Nephrol. 2016;11(7):1163-72. https://doi.org/10.2215/CJN.10441015.

52. Inker LA, Levey AS, Pandya K, Stoycheff N, Okparavero A, Greene T, et al. Early change in proteinuria as a surrogate end point for kidney disease progression: an individual patient metaanalysis. Am J Kidney Dis. 2014;64(1):74-85. https://doi.org/10. 1053/j.ajkd.2014.02.020.

53. Nicholas SB, Kalantar-Zadeh K, Norris KC. Racial disparities in kidney disease outcomes. Semin Nephrol. 2013;33(5):409-15. https://doi.org/10.1016/j.semnephrol.2013.07.002.

54. Nicholas SB, Kalantar-Zadeh K, Norris KC. Socioeconomic disparities in chronic kidney disease. Adv Chronic Kidney Dis. 2015;22(1):6-15. https://doi.org/10.1053/j.ackd.2014.07.002.

55. Kurella Tamura M, Anand S, Li S, Chen SC, Whaley-Connell AT, Stevens LA, et al. Comparison of CKD awareness in a screening population using the Modification of Diet in Renal Disease (MDRD) study and CKD Epidemiology Collaboration (CKDEPI) equations. Am J Kidney Dis. 2011;57(3 Suppl 2):S17-23. https://doi.org/10.1053/j.ajkd.2010.11.008.

56. Ene-Iordache B, Perico N, Bikbov B, Carminati S, Remuzzi A, Perna $\mathrm{A}$, et al. Chronic kidney disease and cardiovascular risk in six regions of the world (ISN-KDDC): a cross-sectional study. Lancet Glob Health. 2016;4(5):e307-19. https://doi.org/10.1016/S2214-109X(16) 00071-1. Provides a global perspective on CKD.

57. Plantinga LC, Boulware LE, Coresh J, Stevens LA, Miller ER 3rd, Saran R, et al. Patient awareness of chronic kidney disease: trends and predictors. Arch Intern Med. 2008;168(20):2268-75. https:// doi.org/10.1001/archinte.168.20.2268.

58. Whaley-Connell A, Bomback AS, McFarlane SI, Li S, Roberts T, Chen SC, et al. Diabetic cardiovascular disease predicts chronic kidney disease awareness in the Kidney Early Evaluation Program. Cardiorenal Med. 2011;1(1):45-52. https://doi.org/10. $1159 / 000322862$

59. Guessous I, McClellan W, Vupputuri S, Wasse H. Low documentation of chronic kidney disease among high-risk patients in a managed care population: a retrospective cohort study. BMC Nephrol. 2009;10(1):25. https://doi.org/10.1186/1471-2369-1025.

60. Tuot DS, Plantinga LC, Hsu CY, Jordan R, Burrows NR, Hedgeman E, et al. Chronic kidney disease awareness among individuals with clinical markers of kidney dysfunction. Clin J Am Soc Nephrol. 2011;6(8):1838-44. https://doi.org/10.2215/CJN.00730111.

61. Bruce MA, Beech BM, Crook ED, Sims M, Wyatt SB, Flessner MF, et al. Association of socioeconomic status and CKD among African Americans: the Jackson Heart Study. Am J Kidney Dis. 2010;55(6):1001-8. https://doi.org/10.1053/j.ajkd.2010.01.016.

62. Choi AI, Weekley CC, Chen SC, Li S, Tamura MK, Norris KC, et al. Association of educational attainment with chronic disease and mortality: the Kidney Early Evaluation Program (KEEP). Am J Kidney Dis. 2011;58(2):228-34. https://doi.org/10.1053/j.ajkd. 2011.02.388.

63. Berkman ND, Sheridan SL, Donahue KE, Halpern DJ, Crotty K. Low health literacy and health outcomes: an updated systematic review. Ann Intern Med. 2011;155(2):97-107. https://doi.org/10. 7326/0003-4819-155-2-201107190-00005.

64. Hall YN, Rodriguez RA, Boyko EJ, Chertow GM, O'Hare AM. Characteristics of uninsured Americans with chronic kidney disease. J Gen Intern Med. 2009;24(8):917-22. https://doi.org/10. 1007/s11606-009-1028-3.

65. Agrawal V, Jaar BG, Frisby XY, Chen SC, Qiu Y, Li S, et al. Access to health care among adults evaluated for CKD: findings from the Kidney Early Evaluation Program (KEEP). Am J Kidney Dis. 2012;59(3 Suppl 2):S5-15. https://doi.org/10.1053/j.ajkd.2011.10. 043.

66. Hughes-Carter DL, Hoebeke RE. Screening for diabetic kidney disease in primary care for the underinsured: a quality improvement initiative. Appl Nurs Res. 2016;30:148-53. https://doi.org/ 10.1016/j.apnr.2015.11.008.

67. Boulware LE, Troll MU, Jaar BG, Myers DI, Powe NR. Identification and referral of patients with progressive CKD: a national study. Am J Kidney Dis. 2006;48(2):192-204. https:// doi.org/10.1053/j.ajkd.2006.04.073.

68. Lea JP, McClellan WM, Melcher C, Gladstone E, Hostetter T. CKD risk factors reported by primary care physicians: do guidelines make a difference? Am J Kidney Dis. 2006;47(1):72-7. https://doi.org/10.1053/j.ajkd.2005.09.027.

69. Stuckey HL, Vallis M, Kovacs Burns K, Mullan-Jensen CB, Reading JM, Kalra S, et al. "I do my best to listen to patients": qualitative insights into DAWN2 (Diabetes psychosocial care from the perspective of health care professionals in the second Diabetes Attitudes, Wishes and Needs Study). Clin Ther. 2015;37(9):1986-98 e12. https://doi.org/10.1016/j.clinthera. 2015.06.010.

70. Sinsky C, Colligan L, Li L, Prgomet M, Reynolds S, Goeders L, et al. Allocation of physician time in ambulatory practice: a time and motion study in 4 specialties. Ann Intern Med. 2016;165(11): 753-60. https://doi.org/10.7326/M16-0961.

71. Martinez-Ramirez HR, Jalomo-Martinez B, Cortes-Sanabria L, Rojas-Campos E, Barragan G, Alfaro G, et al. Renal function preservation in type 2 diabetes mellitus patients with early nephropathy: a comparative prospective cohort study between primary health care doctors and a nephrologist. Am J Kidney Dis. 2006;47(1):78-87. https://doi.org/10.1053/j.ajkd.2005.09.015.

72. Jones C, Roderick P, Harris S, Rogerson M. Decline in kidney function before and after nephrology referral and the effect on survival in moderate to advanced chronic kidney disease. Nephrol Dial Transplant. 2006;21(8):2133-43. https://doi.org/10.1093/ndt/gfl198.

73. Winkelmayer WC, Owen WF Jr, Levin R, Avorn J. A propensity analysis of late versus early nephrologist referral and mortality on dialysis. J Am Soc Nephrol. 2003;14(2):486-92. https://doi.org/ 10.1097/01.ASN.0000046047.66958.C3. 
74. Kohan DE. Training the next generation of nephrologists. Clin J Am Soc Nephrol. 2011;6(11):2564-6. https://doi.org/10.2215/ CJN.08940811.

75. Sharif MU, Elsayed ME, Stack AG. The global nephrology workforce: emerging threats and potential solutions! Clin Kidney J. 2016;9(1):11-22. https://doi.org/10.1093/ckj/sfv111.

76. KDIGO. 2012 Clinical practice guideline for the evaluation and management of chronic kidney disease. Kidney Int Suppl. 2013;3(1):1-150.

77. Vassalotti JA, Centor R, Turner BJ, Greer RC, Choi M, Sequist TD, et al. Practical approach to detection and management of chronic kidney disease for the primary care clinician. Am J Med. 2016;129(2): 153-62 e7. https://doi.org/10.1016/j.amjmed.2015.08.025.

78. Gillespie BW, Morgenstern H, Hedgeman E, Tilea A, Scholz N, Shearon $\mathrm{T}$, et al. Nephrology care prior to end-stage renal disease and outcomes among new ESRD patients in the USA. Clin Kidney J. 2015;8(6):772-80. https://doi.org/10.1093/ckj/sfv103.

79. Nee R, Yuan CM, Hurst FP, Jindal RM, Agodoa LY, Abbott KC. Impact of poverty and race on pre-end-stage renal disease care among dialysis patients in the United States. Clin Kidney J. 2017;10(1):55-61. https://doi.org/10.1093/ckj/sfw098

80. Khunti K, Wolden ML, Thorsted BL, Andersen M, Davies MJ. Clinical inertia in people with type 2 diabetes: a retrospective cohort study of more than 80,000 people. Diabetes Care. 2013;36(11):3411-7. https://doi.org/10.2337/dc13-0331.

81. Desai N, Madhavankutty Saraswathy V, Hunter K, McFadden C. Prevalence of true therapeutic inertia in blood pressure control in an academic chronic kidney disease clinic. J Clin Hypertens (Greenwich). 2013;15(6):375-9. https://doi.org/10.1111/jch.12095.

82. Bailie GR, Eisele G, Liu L, Roys E, Kiser M, Finkelstein F, et al. Patterns of medication use in the RRI-CKD study: focus on medications with cardiovascular effects. Nephrol Dial Transplant. 2005;20(6):1110-5. https://doi.org/10.1093/ndt/gfh771.

83. Muntner P, Judd SE, Krousel-Wood M, McClellan WM, Safford MM. Low medication adherence and hypertension control among adults with CKD: data from the REGARDS (Reasons for Geographic and Racial Differences in Stroke) study. Am J Kidney Dis. 2010;56(3):447-57. https://doi.org/10.1053/j.ajkd. 2010.02.348.

84. Lam WY, Fresco P. Medication adherence measures: an overview. Biomed Res Int. 2015;2015:217047.

85. Narva AS, Bilous RW. Laboratory assessment of diabetic kidney disease. Diabetes Spectr. 2015;28(3):162-6. https://doi.org/10. 2337/diaspect.28.3.162.

86. Drawz PE, Archdeacon P, McDonald CJ, Powe NR, Smith KA, Norton J, et al. CKD as a model for improving chronic disease care through electronic health records. Clin J Am Soc Nephrol. 2015;10(8):1488-99. https://doi.org/10.2215/CJN.00940115.

87. Tuot DS, Diamantidis CJ, Corbett CF, Boulware LE, Fox CH, Harwood DH, et al. The last mile: translational research to improve CKD outcomes. Clin J Am Soc Nephrol. 2014;9(10):18025. https://doi.org/10.2215/CJN.04310514.

88. Narva AS, Norton JM, Boulware LE. Educating patients about CKD: the path to self-management and patient-centered care. Clin J Am Soc Nephrol. 2016;11(4):694-703. https://doi.org/10. 2215/CJN.07680715

89. Norton JM, Moxey-Mims MM, Eggers PW, Narva AS, Star RA, Kimmel PL, et al. Social determinants of racial disparities in CKD. J Am Soc Nephrol. 2016;27(9):2576-95. https://doi.org/10.1681/ ASN.2016010027.

90. Goldstein K, Briggs M, Oleynik V, Cullen M, Jones J, Newman E, et al. Using digital media to promote kidney disease education. Adv Chronic Kidney Dis. 2013;20(4):364-9. https://doi.org/10. 1053/j.ackd.2013.04.001.

91. Bear RA, Stockie S. Patient engagement and patient-centred care in the management of advanced chronic kidney disease and chronic kidney failure. Can J Kidney Health Dis. 2014;1:24. https://doi.org/10.1186/s40697-014-0024-7.

92. Wright Nunes J, Greene JH, Wallston K, Eden S, Shintani A, Elasy T, et al. Pilot study of a physician-delivered education tool to increase patient knowledge about CKD. Am J Kidney Dis. 2013;62(1):23-32. https://doi.org/10.1053/j.ajkd.2013.01.023.

93. Wright-Nunes JA, Luther JM, Ikizler TA, Cavanaugh KL. Patient knowledge of blood pressure target is associated with improved blood pressure control in chronic kidney disease. Patient Educ Couns. 2012;88(2):184-8. https://doi.org/10.1016/j.pec.2012.02.015.

94. Devins GM, Mendelssohn DC, Barre PE, Taub K, Binik YM. Predialysis psychoeducational intervention extends survival in CKD: a 20-year follow-up. Am J Kidney Dis. 2005;46(6):108898. https://doi.org/10.1053/j.ajkd.2005.08.017.

95. Devins GM, Mendelssohn DC, Barre PE, Binik YM. Predialysis psychoeducational intervention and coping styles influence time to dialysis in chronic kidney disease. Am J Kidney Dis. 2003;42(4): 693-703. https://doi.org/10.1016/S0272-6386(03)00835-7.

96. Cavanaugh K, Wallston KA, Gebretsadik T, Shintani A, Huizinga MM, Davis D, et al. Addressing literacy and numeracy to improve diabetes care: two randomized controlled trials. Diabetes Care. 2009;32(12):2149-55. https://doi.org/10.2337/dc09-0563.

97. Galbraith L, Hemmelgarn B, Manns B, Samuel S, Kappel J, Valk $\mathrm{N}$, et al. The association between individual counselling and health behaviour change: the See Kidney Disease (SeeKD) targeted screening programme for chronic kidney disease. Can J Kidney Health Dis. 2016;3:35.

98. National Institutes of Health. National Kidney Disease Education Program (NKDEP). [cited 2017 February 2]. Available from: https://www.niddk.nih.gov/health-information/healthcommunication-programs/nkdep/Pages/default.aspx.

99. Fadem SZ. State of the art: chronic kidney disease education. Dial Transplant. 2011;40(9):397-400. https://doi.org/10.1002/dat. 20606.

100. Pagels AA, Hylander B, Alvarsson M. A multi-dimensional support programme for patients with diabetic kidney disease. J Ren Care. 2015;41(3):187-94. https://doi.org/10.1111/jorc.12114.

101. National Kidney Foundation. [cited 2017 February 2]. Available from: https://www.kidney.org/professionals/KLS/cmeprograms.

102. Medical Education Institute. [cited 2017 February 2]. Available from: https://meiresearch.org.

103. Renal Physicians Association. [cited 2017 February 2]. Available from: http://rpa.mycrowdwisdom.com/diweb/home.

104. Moyer VA, Force USPST. Screening for chronic kidney disease: U.S. Preventive Services Task Force recommendation statement. Ann Intern Med. 2012;157(8):567-70. https://doi.org/10.7326/ 0003-4819-157-8-201210160-00533.

105. Qaseem A, Hopkins RH Jr, Sweet DE, Starkey M, Shekelle P, Clinical Guidelines Committee of the American College of Physicians. Screening, monitoring, and treatment of stage 1 to 3 chronic kidney disease: a clinical practice guideline from the American College of Physicians. Ann Intern Med. 2013;159(12):835-47. https://doi.org/ 10.7326/0003-4819-159-12-201312170-00726.

106. American Socity of Nephrology. ASN emphasizes need for early detection of kidney disease, a silent killer. 2013 [cited 2017 May 10]. Available from: https://www.asn-online.org/news/2013/ ASN_COMM_ACP_Screening_Response_102213_R12.pdf.

107. Hoerger TJ, Wittenborn JS, Zhuo X, Pavkov ME, Burrows NR, Eggers $\mathrm{P}$, et al. Cost-effectiveness of screening for microalbuminuria among African Americans. J Am Soc Nephrol. 2012;23(12):203541. https://doi.org/10.1681/ASN.2012040347.

108. Hoerger TJ, Wittenborn JS, Segel JE, Burrows NR, Imai K, Eggers $\mathrm{P}$, et al. A health policy model of CKD: 2. The costeffectiveness of microalbuminuria screening. Am J Kidney Dis. 2010;55(3):463-73. https://doi.org/10.1053/j.ajkd.2009.11.017. 
109. Komenda P, Ferguson TW, Macdonald K, Rigatto C, Koolage C, Sood MM, et al. Cost-effectiveness of primary screening for CKD: a systematic review. Am J Kidney Dis. 2014;63(5):789-97. https://doi.org/10.1053/j.ajkd.2013.12.012.

110. Boulware LE, Jaar BG, Tarver-Carr ME, Brancati FL, Powe NR. Screening for proteinuria in US adults: a cost-effectiveness analysis. JAMA. 2003;290(23):3101-14. https://doi.org/10.1001/jama. 290.23.3101.

111. Yarnoff BO, Hoerger TJ, Simpson SK, Leib A, Burrows NR, Shrestha SS, et al. The cost-effectiveness of using chronic kidney disease risk scores to screen for early-stage chronic kidney disease. BMC Nephrol. 2017;18(1):85. https://doi.org/10.1186/s12882-017-0497-6.

112. American Diabetes Association. Standards of medical care in diabetes. Diabetes Care. 2017;40(suppl 1):s1-s129.

113. Sarafidis PA, Riehle J, Bogojevic Z, Basta E, Chugh A, Bakris GL. A comparative evaluation of various methods for microalbuminuria screening. Am J Nephrol. 2008;28(2):324-9. https://doi.org/10.1159/000111825.

114. Whaley-Connell AT, Sowers JR, Stevens LA, McFarlane SI, Shlipak MG, Norris KC, et al. CKD in the United States: Kidney Early Evaluation Program (KEEP) and National Health and Nutrition Examination Survey (NHANES) 1999-2004. Am J Kidney Dis. 2008;51(4 Suppl 2):S13-20. https://doi.org/10.1053/ j.ajkd.2007.12.016.

115. Bello AK, Peters J, Wight J, El Nahas M. The Kidney Evaluation and Awareness Program in Sheffield (KEAPS): a community-based screening for microalbuminuria in a British population. Nephron Clin Pract. 2010;116(2):c95-103. https://doi.org/10.1159/000314658.

116. Mathew TH, Corso O, Ludlow M, Boyle A, Cass A, Chadban SJ, et al. Screening for chronic kidney disease in Australia: a pilot study in the community and workplace. Kidney Int Suppl. 2010;116:S9-16.

117. Jolly SE, Li S, Chen SC, Narva AS, Jurkovitz CT, Norris KC, et al. Risk factors for chronic kidney disease among American Indians and Alaska Natives - findings from the Kidney Early Evaluation Program. Am J Nephrol. 2009;29(5):440-6. https://doi.org/10. $1159 / 000174857$

118. Hwang SJ, Tsai JC, Chen HC. Epidemiology, impact and preventive care of chronic kidney disease in Taiwan. Nephrology (Carlton). 2010;15(Suppl 2):3-9. https://doi.org/10.1111/j.14401797.2010.01304.x.

119. Satko SG, Sedor JR, Iyengar SK, Freedman BI. Familial clustering of chronic kidney disease. Semin Dial. 2007;20(3):229-36. https://doi.org/10.1111/j.1525-139X.2007.00282.x.

120. Levey AS, Inker LA, Coresh J. GFR estimation: from physiology to public health. Am J Kidney Dis. 2014;63(5):820-34. https:// doi.org/10.1053/j.ajkd.2013.12.006.

121. Accetta NA, Gladstone EH, DiSogra C, Wright EC, Briggs M, Narva AS. Prevalence of estimated GFR reporting among US clinical laboratories. Am J Kidney Dis. 2008;52(4):778-87. https://doi.org/10.1053/j.ajkd.2008.05.023.

122. Schievink B, Kropelin T, Mulder S, Parving HH, Remuzzi G, Dwyer J, et al. Early renin-angiotensin system intervention is more beneficial than late intervention in delaying end-stage renal disease in patients with type 2 diabetes. Diabetes Obes Metab. 2016;18(1):64-71. https://doi.org/10.1111/dom.12583.

123. Taal MW. Predicting renal risk in the general population: do we have the right formula? Clin J Am Soc Nephrol. 2011;6(7):15235. https://doi.org/10.2215/CJN.04200511.

124. Echouffo-Tcheugui JB, Kengne AP. Risk models to predict chronic kidney disease and its progression: a systematic review. PLoS Med. 2012;9(11):e1001344. https://doi.org/10.1371/journal. pmed.1001344.

125. Dunkler D, Gao P, Lee SF, Heinze G, Clase CM, Tobe S, et al. Risk prediction for early CKD in type 2 diabetes. Clin J Am Soc Nephrol. 2015;10(8):1371-9. https://doi.org/10.2215/CJN.10321014.
126. Halbesma N, Jansen DF, Heymans MW, Stolk RP, de Jong PE, Gansevoort RT, et al. Development and validation of a general population renal risk score. Clin J Am Soc Nephrol. 2011;6(7): 1731-8. https://doi.org/10.2215/CJN.08590910.

127. Perotte A, Ranganath R, Hirsch JS, Blei D, Elhadad N. Risk prediction for chronic kidney disease progression using heterogeneous electronic health record data and time series analysis. J Am Med Inform Assoc. 2015;22(4):872-80. https://doi.org/10.1093/jamia/ocv024.

128. Schutte E, Gansevoort RT, Benner J, Lutgers HL, Lambers Heerspink HJ. Will the future lie in multitude? A critical appraisal of biomarker panel studies on prediction of diabetic kidney disease progression. Nephrol Dial Transplant. 2015;30(Suppl 4): iv96-104. https://doi.org/10.1093/ndt/gfv119.

129. Tangri N, Stevens LA, Griffith J, Tighiouart H, Djurdjev O, Naimark D, et al. A predictive model for progression of chronic kidney disease to kidney failure. JAMA. 2011;305(15):1553-9. https://doi.org/10.1001/jama.2011.451.

130. Johns TS, Yee J, Smith-Jules T, Campbell RC, Bauer C. Interdisciplinary care clinics in chronic kidney disease. BMC Nephrol. 2015;16(1):161. https://doi.org/10.1186/s12882-015-0158-6.

131. Bayliss EA, Bhardwaja B, Ross C, Beck A, Lanese DM. Multidisciplinary team care may slow the rate of decline in renal function. Clin J Am Soc Nephrol. 2011;6(4):704-10. https://doi. org/10.2215/CJN.06610810.

132. Chen PM, Lai TS, Chen PY, Lai CF, Yang SY, Wu V, et al. Multidisciplinary care program for advanced chronic kidney disease: reduces renal replacement and medical costs. Am J Med. 2015;128(1):68-76. https://doi.org/10.1016/j.amjmed.2014.07.042.

133. McKenzie AL, Hallberg SJ, Creighton BC, Volk BM, Link TM, Abner MK, et al. A novel intervention including individualized nutritional recommendations reduces hemoglobin alc level, medication use, and weight in type 2 diabetes. JMIR Diabetes. 2017;2(1):e5. https://doi.org/10.2196/diabetes.6981.

134. Chen F, Su W, Becker SH, Payne M, Castro Sweet CM, Peters AL, et al. Clinical and economic impact of a digital, remotely-delivered intensive behavioral counseling program on Medicare beneficiaries at risk for diabetes and cardiovascular disease. PLoS One. 2016;11(10): e0163627. https://doi.org/10.1371/journal.pone.0163627.

135.• Molitch ME, Adler AI, Flyvbjerg A, Nelson RG, So WY, Wanner C, et al. Diabetic kidney disease: a clinical update from Kidney Disease: Improving Global Outcomes. Kidney Int. 2015;87(1): 20-30. https://doi.org/10.1038/ki.2014.128. Discusses a number of areas in the management of DKD.

136. Gaede P, Vedel P, Larsen N, Jensen GV, Parving HH, Pedersen O. Multifactorial intervention and cardiovascular disease in patients with type 2 diabetes. N Engl J Med. 2003;348(5):383-93. https:// doi.org/10.1056/NEJMoa021778.

137.• Oellgaard J, Gaede P, Rossing P, Persson F, Parving HH, Pedersen O. Intensified multifactorial intervention in type 2 diabetics with microalbuminuria leads to long-term renal benefits. Kidney Int. 2017. Discusses the impact of intensified, multifactorial treatment on renal outcomes in patients with DKD.

138. Crowley ST, Belcher J, Choudhury D, Griffin C, Pichler R, Robey $\mathrm{B}$, et al. Targeting access to kidney care via telehealth: the VA experience. Adv Chronic Kidney Dis. 2017;24(1):22-30. https:// doi.org/10.1053/j.ackd.2016.11.005.

139. Haley WE, Beckrich AL, Sayre J, McNeil R, Fumo P, Rao VM, et al. Improving care coordination between nephrology and primary care: a quality improvement initiative using the renal physicians association toolkit. Am J Kidney Dis. 2015;65(1):67-79. https://doi.org/10.1053/j.ajkd.2014.06.031.

140. Jolly SE, Navaneethan SD, Schold JD, Arrigain S, Konig V, Burrucker YK, et al. Development of a chronic kidney disease patient navigator program. BMC Nephrol. 2015;16(1):69. https://doi.org/10.1186/s12882-015-0060-2. 